\title{
THE LEGISLATIVE VETO FROM THE PERSPECTIVE OF THE KOSOVO CONSTITUTION
}

\author{
Visar Morina*
}

\begin{abstract}
The Constitution of Kosovo has established a number of mechanisms for the separation of powers and reciprocal checks and balances among which is the President's authority to return legislation for reconsideration. However, the interaction between the President and the Assembly on matters confronting the legislative veto has unveiled a number of constitutional ambiguities and inconsistencies which rendered involvement of the Constitutional Court necessary to define further the constitutionallycontemplated powers of the President for returning legislation for reconsideration. The article analyses the Presidential legislative veto from the prospect of the 2008 Kosovo Constitution. Through constitutional interpretation and practical cases this article seeks to examine more closely the structural and the functional aspect of the Presidential legislative return statements in post-status Kosovo.
\end{abstract}

\section{INTRODUCTION}

One of the striking features of the Kosovo Constitution is the principle of the separation of powers between the legislative, executive and the judicial branch. The separation of powers serves at least two essential functions in this new democracy. First, it aims to ensure that the power sharing is appropriately divided and balanced among the three branches of government, and second, that the exercise of the power is reciprocally checked and controlled on the basis of the checks and balances principle. One of these balancing powers is the right of the President of the Republic to veto legislation enacted by the Assembly of Kosovo (hereinafter "Assembly") if the President (hereinafter "the President") determines that the enacted legislation is constitutionally suspect or violates substantial state or national interests. To some scholars, the

\footnotetext{
* Prof. Dr. Visar Morina is a lecturer of constitutional law at the University of Prishtina in Kosovo and member of the Steering Committee of the Kosovo Chamber of Advocates. I would like to express my gratitude to Professor Brian Anderson who has provided insightful comments for this article.
} 


\section{THE LEGISLATIVE VETO FROM THE PERSPECTIVE OF THE KOSOVO CONSTITUTION}

President's right to return parliamentary-enacted laws for reconsideration is nothing but a mere constitutional shield of the community rights. Some argue, however, that the President's legislative veto is a reflection of the checks and balances embodied in article 4 of the 2008 Kosovo Constitution. The occasional use of the Presidential legislative veto, however, has attracted wide attention among the legal community in Kosovo. With the growing legislative initiatives, the public and civil society organisations have occasionally called upon the President to block legislative attempts that were considered to be incompatible with constitutional norms. The President's legislative veto and procedure for its override by the Assembly was also subject of the Kosovo Constitutional Court, which testifies the importance of this legislative instrument in this new democracy. Considering the above-mentioned challenges, this article undertakes a broader legal analysis of the application of the President's right to return legislation from the perspective of the Kosovo Constitution. As such, it will complement the existing academic literature on two major accounts. First, this article strives to supplement the academic discourse regarding the presidential powers in the legislative review prior to law promulgation, which remains relatively scant on this important subject. Second, this article will fill the gap in the current literature regarding certain structural aspects that are generally not addressed by constitutional norms but which normally require further legal elaboration regarding the interaction between the legislative and the executive branch on law promulgation in the parliamentary-type of governments.

Following the introduction, this article will initially analyse the powers of the President in the context of the 2008 Kosovo Constitution. Section 3 of the article outlines the process of legal drafting in Kosovo while in section 4 focus turns to a critical examination of the constitutional interaction between the President and the Assembly in accommodating the presidential concerns over the enacted legislation. This part of the article seeks to demarcate the boundaries of the Presidential review of law-enactments prior to their promulgation focusing on both constitutionally enumerated and self-implied categories within parameters contemplated by the Kosovo Constitution. After having explored the application of the legislative veto in both procedural and substantive grounds, section 5 will focus on the challenges and constraints which the respective constitutional bodies in Kosovo have encountered in dealing with a presidential legislative veto and its legal implications to the overall legal drafting process. 


\section{A BRIEF OVERVIEW OF THE CONSTITUTIONAL COMPETENCIES OF THE PRESIDENT}

As one of the latest constitutions in a world, the 2008 Kosovo Constitution follows patterns of modern constitutions by following the concept of powerdivision and human rights protection to limit the potential power abuse of the governmental institutions. The Constitution provides for an extensive list of constitutional rights and freedoms (Chapter 2 of the Constitution) and provides for a direct application of the European Convention for the Protection of Human Rights and Fundamental Freedoms and its Protocols (Arts 22 and 53 of the Constitution). It is also worth pointing out that the Constitution has devoted a special chapter to the community rights, which contains specific rights for the members of the non-majority communities in addition to the human rights provided in chapter 2 of the Constitution. The principle of the separation of powers, which now enjoys wide acceptance in modern constitutional democracies, is therefore one of the key principles entrenched in the Kosovo Constitution. ${ }^{1}$ The Constitution in its article 4 provides that "Kosovo is a democratic Republic based on the principle of separation of powers and the checks and balances among them as provided in this Constitution.” The 120 member Assembly is entitled to exercise the legislative power while the President of the Republic represents the unity of the people. ${ }^{2}$ The judicial power is vested with the courts while the Constitutional Court is empowered to conduct constitutional review and make binding constitutional interpretations. ${ }^{3}$ The nine-member Constitutional Court is entitled to engage in the so-called abstract review of constitutionality and serves as a final protector of the constitutional rights and freedoms.

However, as powers allocated to each branch of the Government are not "hermetically" sealed from one another and to ensure that the constitutional powers are allocated equally, the Kosovo Constitution has introduced the principle of checks and balances where the authority of one organ is controlled and checked by the authority of the other organ. Some of those reciprocal controls and the constitutional choices are typical for a parliamentary type of government. For example, the President of the Republic is elected by two thirds (2/3) majority of all deputies of the Assembly, but the

\footnotetext{
${ }^{1}$ Constitution of the Republic of Kosovo was proclaimed on 9 April 2008 and entered into force 15 June 2008 (Constitution). For more on the Kosovo Constitution see Joseph Marko, 'The new Constitution of Kosovo from the regional perspective' (2008) 33 Review of Central and European Law 437; John Tunheim, "Rule of Law and the Kosovo Constitution” (2009) 18 Minnesota Journal of International Law 371; Arsim Bajrami, Sistemi Kushtetues i Republikës së Kosovës (2011) Artini.

${ }^{2}$ Constitution (n 1) art 64 and 84.

${ }^{3}$ Constitution (n 1) art 102 and 112.
} 


\section{THE LEGISLATIVE VETO FROM THE PERSPECTIVE OF THE KOSOVO CONSTITUTION}

President can dissolve the Assembly following a successful vote of no confidence against the Government. ${ }^{4}$ Similarly, the majority of deputies of the Assembly adopt laws, decisions and other acts, but the President is entitled to return a law to the Assembly by stating the reasons of return. These reciprocal checks are inevitable for a balanced institutional interaction among state institutions, which using Carolan reflections on the separation of powers indicate that "the extensive powers exercised by the organs of the state could never be satisfactorily reduced to a simplistic three-way of allocation of tasks." ${ }^{5}$ Presidential competencies are contemplated by Article 84 of the Constitution. However, as will be seen in the following section of this article, the President is independent to discharge only certain constitutional competencies; other powers of the President are either shared with or depend on the authority of other constitutional bodies. ${ }^{6}$

The President initiates decision of another organ: The Constitution has introduced certain constitutional choices in which the President only initiates the decision of another constitutional body but the President is prevented from the authority to decide the matter on his own. For example the President is competent to initiate a procedure for compliance of a law with the Constitution but the final decision rests ultimately with the Constitutional Court. ${ }^{7}$ Likewise, the President may initiate the procedure to have an enacted law be reconsidered by the Assembly prior to its promulgation but the Assembly's repeated enactment of a law enables the law to enter into force in absence of President's endorsement. ${ }^{8}$ It should be noted that these kind of constitutional choices are common for some parliamentary-type constitutions in the European level in order to keep the constitutional balance of power intact.

The President's decision ratifies the decision of another organ: In addition to above, the Constitution has foreseen other limitations in the constitutional authority of the President to prevent the President from exercising independent constitutional competencies. These limitations have particularly been introduced to safeguard and protect the independence of the judiciary, including that of the Constitutional Court, where a decision of the President

\footnotetext{
${ }^{4}$ Constitution (n 1) art 82 para 2.

${ }^{5}$ Eoin Carolan, The New Separation of Powers: A Theory for the Modern State (OUP, 2009) 19.

${ }^{6}$ This categorisation of the competencies of the President has been borrowed from the Judgment of the Hungarian Constitutional Court No. 48/1991 on Presidential Powers (1991).

${ }^{7}$ Constitution (n 1 ) art 113 para 2.

${ }^{8}$ Constitution (n 1) art 84 para 6.
} 
depends on the authority of the organ and, as such, the President is not permitted to exercise a particular function on his own initiative. Examples of these are where the President under Article 84 (15) and (16) of the Constitution appoints and dismisses the President of the Supreme Court and other Judges under the proposal of the Kosovo Judicial Council. The reading of the respective articles of the Constitution clearly implies that the President is authorised to take a decision for the appointment or dismissal of regular judges only based upon a reasoned proposal of the Kosovo Judicial Council. It is also assumed that the President is not allowed to appoint a candidate not included on the list submitted by the Kosovo Judicial Council for appointment. Also under Article 84 (17) and (18) of the Constitution the President appoints and dismisses the Chief Prosecutor and prosecutors upon the proposal of the Kosovo Prosecutorial Council. What remains unclear from a constitutional point of view is whether the constitutional concept of the President's power of appointment includes the right to refuse the appointment. In general, it may be considered that the President is bound to accept the choice of the nominated person, and may reject the proposed candidate on very exceptional grounds if he/she has well founded convictions that such appointment might seriously disturb the democratic functioning of the state organisations as provided by art. 84.2 of the Constitution.

President's decision is decisive: The category of independent presidential competencies comprises those competencies that are attributable to the President by the Constitution and are considered sole constitutional responsibilities. The President is entitled to exercise these constitutional powers independently from other constitutional organs, and the decision of the President is decisive. For example, under Article 69.4 of the Constitution the President may convene an extraordinary meeting of the Assembly of Kosovo. Further, under Article 139 of the Constitution the President appoints the Chairperson of the Central Elections Commission from among the Judges of the Supreme Court. The President may also take independent political decisions also when serious disturbances in the State's democratic functioning require his intervention. With such intervention the President fulfils his duties set out in Article 84 (2) of the Constitution "guarantees the constitutional functioning of the institutions set forth by this Constitution." According to the Constitution such cases may arise if the government cannot be established within 60 days from the date when the President of the Republic appoints the candidate for Prime Minister. In this case the President dissolves the Parliament while simultaneously setting the date for new elections. 


\section{THE LEGISLATIVE VETO FROM THE PERSPECTIVE OF THE KOSOVO CONSTITUTION}

\section{THE LEGISLATIVE PROCEDURE}

Having explored the constitutional competences of the President, we will now turn to elaborate in broader terms the legislative process in Kosovo. It should be mentioned, however, that not much has been written in this field in Kosovo except some documents and guidelines published by the government from time to time. These guidelines were published as an effort to increase the legal drafting capacities in Kosovo, in particular when it comes to the process of converting governmental policies into legal drafting instruments, and ensuring compliance with European Union legislation. The right to legislative initiative is given to the President of the Republic of Kosovo, the Government, deputies of the Assembly or at least ten thousand citizens. ${ }^{9}$ It should be noted that the President can exercise the right to initiate legislation only within the ambit of its constitutional authority. Such was the case with the Law on the President and the Law on Pardon. ${ }^{10}$ Obviously, the power to initiate drafting of legislation is mainly used by the Government, which implements the parliamentary approved program through the enactment of legislation whereas legal drafting initiatives by the Assembly of Kosovo have been rarely undertaken. ${ }^{11}$

The procedure for the referral of legislative initiatives and the procedure for the presentment of the draft laws for parliamentary scrutiny are further regulated by the Law on the Legislative Initiative and the Rules of Procedure of the Assembly of Kosovo. ${ }^{12}$ The initiating authority is obliged to send the announcement for the commencement of the initiative to appropriate table unit at the Assembly, requiring provision of detailed explanation as to the objectives aimed to be implemented. ${ }^{13}$ The initiating authority should provide an explanation note stating the objectives that are aimed to be achieved and the declaration on the potential budgetary implications of the draft law for the

\footnotetext{
${ }^{9}$ Constitution (n 1) art 79.

10 Law no. 03/l-101 on Pardon was adopted on 12 December 2008 and was promulgated by the Decree No. DL-076-2008 dated 30.12.2008. The Law on the Law No. 03/L-094 was adopted on 19 December 2008 and was promulgated by the Decree No. DL-082-2008, dated 07.01.2009.

11 One of a few legal drafting initiatives that were undertaken by the Assembly include the Law on the Rights and Obligations of the Deputies of the Assembly of Kosovo, the Law on Mines and Minerals and the Law on Pension Fund.

12 Law on Legislative Initiative No 04/L-025 was approved by the Assembly of Kosovo on 6 October 2011. The Law is available at the Official Gazette of Kosovo http:/gazetazyrtare.rks-gov.net/.

${ }^{13}$ Law on Legislative Initiative, art 13.
} 
first three years. Furthermore, a declaration of the approximation and harmonisation of the proposed law with EU legislation is also required. ${ }^{14}$

Once presented to the Assembly, the draft law is subject to the first reading (discussion and voting of the draft law in principle), which takes place no earlier than two working weeks and no later than four working weeks, from the day of the distribution of the draft law to the members of the Assembly. ${ }^{15}$ The first reading of the draft law commences with its presentation by the sponsor, and continues with presentations by the rapporteur of the functional committee, representatives of parliamentary groups and members of the Assembly. ${ }^{16} \mathrm{~A}$ voting in principle concludes the first reading. Following the approval of the draft law in the first reading, the Assembly assigns for further review one of the Functional Committees as lead committee and the main Committees. ${ }^{17}$ The leading committee reviews all submitted amendments and decides whether to take them into consideration when preparing a new text of the draft law. Amendments to the draft law may be introduced by a Member of the Assembly, parliamentary group, parliamentary committee, and the government, within two working weeks from the approval in principle. The second reading commences with a presentation of the report of the leading committee. Once the report is presented, representatives of main committees, representatives of parliamentary groups, representatives of the Government and members of the Assembly are entitled to discuss and present comments regarding the proposed amendments. ${ }^{18}$ The second reading of draft law continues by a review and voting on the proposed amendments to be followed with an adoption of the draft law in its entirety. ${ }^{19}$ It should be noted that when a draft law does not receive the sufficient number of votes for its adoption in the second reading, the Assembly upon the request of the sponsor of the draft law can decide to present the draft law to a third reading together with the adopted amendments. ${ }^{20}$ However, those amendments that were rejected in the second reading or those the content of which is similar with amendments of the

\footnotetext{
${ }^{14}$ Rules of Procedure of the Assembly of Kosovo, art 54 (Rules of Procedure).

${ }^{15}$ Rules of Procedure (n 14) art 56 para 2.

${ }^{16}$ Rules of Procedure (n 14) art 56 para 4.

17 Rules of Procedure (n 14) art 57 para 1. The main Committees include: the Committee for Legislation and Judiciary; the Committee for Budget and Finance; the Committee for European Integrations; the Committee for Human Rights; Gender Equality, Missing Persons and Petitions; and the Committee for Rights and Interests of Communities and Returns.

${ }^{18}$ Rules of Procedure (n 14) art 58 para 1.

${ }^{19}$ Rules of Procedure (n 14) art 58.

${ }^{20}$ Rules of Procedure (n 14) art 58.
} 


\section{THE LEGISLATIVE VETO FROM THE PERSPECTIVE OF THE KOSOVO CONSTITUTION}

second reading cannot not be presented for the third reading. ${ }^{21}$ The law adopted by the Assembly is signed by the Chairman of the Assembly within ten working days from the day of its adoption, following which is sent to the President of the Republic for promulgation. ${ }^{22}$

The legislative drafting process is concluded when the President promulgates a law, which occurs within 8 days from the receipt of a law. But a law enters into force fifteen (15) days after its publication in the Official Gazette of the Republic of Kosovo except when otherwise specified by the law itself. ${ }^{23}$ This is of course only a general description of the main phases of the law drafting process in Kosovo, which may be considered to have been sufficiently regulated in Kosovo by way of laws and regulations. But the legislative process yet remains a complex undertaking and is often considered to be a challenge for drafting authorities in Kosovo to deliver qualitative legislative products. Linguistic ambiguity, legal inconsistency and sometimes lack of big-picture policy considerations still compromise legislative integrity. In this regard, better communication and cooperation between the three branches of the government needs to be fostered to ensure unification of legal drafting techniques and streamline the law making process at all levels. In particular, it is of great importance for the drafting authorities in Kosovo to pay more attention to the policy analysis before the drafting of legislation begins. This is essential to ensure a well-drafted and properly implemented law in a longer run.

\section{LEGISLATIVE VETO: A STRUCTURAL ANALYSIS}

Although the Constitution does not employ the specific term "veto", the content of article 84 para. 6 of the Constitution clearly suggests that the President has the right to temporarily prevent entry into force of a law enacted by the Assembly if it considers that a law is harmful to the legitimate interests of Kosovo or one or more Communities. ${ }^{24}$ This structural arrangement

\footnotetext{
${ }^{21}$ Rules of Procedure (n 14) art 59 para 2.

${ }^{22}$ Rules of Procedure (n 14) art 61 paras $1-2$.

${ }^{23}$ Constitution (n 1 ) art 80 para 6.

${ }^{24}$ Constitution (n 1) art 84 para 6. For more on presidential legislative veto in the general context see Chad Eggspuehler, 'The S-Words Mightier than the Pen: Signing Statements as Express Advocacy of Unlawful Action’ [2007/2008] 41 Gonz. L. Rev. 461; Courtney Odishaw, "Curbing Legislative Chaos: Executive Choice or Congressional Responsibility?” [1998] 74 Iowa L. Rev 277; Michael Rappaport, 'The President's Veto and the Constitution’ [1992] 87 Nw. U.L. Rev. 736; Aaron Zibart, "Eulogizing the Line Item Veto Act: Clinton v City of New York and the Wisdom of Presidential Legislating” [1999/2000] 88 Ky. L.J. 505; Sofia Biller, "Flooded by the Lowest Ebb: Congressional Responses to Presidential Signing Statements and
} 
suggests that the Constitution has provided for a qualified negative legislative veto, whose exercise depends on the grounds contemplated by the Constitution. There are two structural grounds for vetoing legislation that are implicit in the Constitution. The rather broad conceptual framework of protection of legitimate interests of the Republic, and the specific adherence to the protection of the community interests. With regard to the latter, the reasons of the Constitution emphasising the importance of protecting the Community interests from parliamentary legislative encroachments are worthy of explanation. The President's involvement for the protection the interests of the Communities in the course of the legislative activities originate from the Constitutional Framework for Provisional Self-Government Institutions in Kosovo, which provided: ${ }^{25}$

"Within 48 hours from the approval of a law by the Assembly pursuant to paragraphs 9.1.37 or 9.1.38 above, any member of the Assembly, supported by five additional members, may submit a motion to the Presidency claiming that the law or certain of its provisions violate vital interests of the Community to which he belongs. The motion shall set out a reasoned explanation of the claimed violation. A motion may be made on the grounds that the law or provisions discriminate against a Community, adversely affect the rights of the Community members under Chapters 3 or 4, or otherwise seriously interfere with the ability of the Community to preserve, protect or express its ethnic, cultural, religious or linguistic identity.”

However, as Bieber argues commenting the exercise of the veto powers in the Bosnia, Kosovo and FYROM, the Constitutional Framework in fact gave "only Serbs, and not the other small communities the possibility of delaying legislation" given the fact that the Constitutional Framework gave Serbs ten guaranteed seats in the Assembly. ${ }^{26}$ This means that only a majority of Serbs were able to challenge the law enacted by the Assembly. The protection of the rights and interest of the communities by presidential veto was further developed by the Comprehensive Proposal for the Kosovo Status Settlement, which authorised the President of Kosovo to "return once to the Assembly for

Executive Hostility to the Operation of Checks and Balances" [2008] 93 Iowa L. Rev. 1067; George Tsebelis, "Veto Players and Law Production in Parliamentary Democracies: An Empirical Analysis” [1999] 93 The American Political Science Review, 591.

${ }^{25}$ Constitutional Framework for the Provisional Institutions of Self-Government in Kosovo 2001 s 9(1)(39).

${ }^{26}$ Sid Noel, From power sharing to democracy: post conflict institutions in ethnically divided societies (McGill Queens University Press, 2005) 96. 


\section{THE LEGISLATIVE VETO FROM THE PERSPECTIVE OF THE KOSOVO CONSTITUTION}

reconsideration any bill he considers detrimental to the legitimate interests of one or more Communities." 27 Hence the Constitution has virtually borrowed the exact formulation of the Comprehensive Proposal in giving the President the legislative veto powers. Today the legislative veto constitutes an appropriate mechanism in the hands of communities to safeguard their rights and interests against constitutionally suspect legislation or parliamentary omnipotence.

The right to return legislation serves essential constitutional functions. First, the President's authority to return constitutionally objectionable laws enables the President to have a share on the legislative process representing the unity of the people. In this representative capacity "the President's most important role is to stave off legislation that might be improved or put aside upon more mature and sedate reflection." ${ }^{28}$ Second, the occasional use of the right to return the adopted law for parliamentary reconsideration enables the President to "contribute to the national constitutional dialogue and thus play a more active role in the scheme of constitutional deliberation." 29 The Presidential engagement in the review of adopted law reinforces the conception that it is not only the courts being engaged in the review of constitutionality of legislation. As Professor Broughton argues "too often, constitutional deliberation is distorted by the mistaken notion that the courts are, or should be the exclusive expositors of the Constitution.” ${ }^{30}$ As some constitutional scholars have argued only a popularly elected President could serve as the "guardian of the constitution." ${ }_{11}$ That said, constitutional deliberation would not be considered alien to other political branches, in particular for a President acting as "pouvoir neuter" in parliamentary democracy promoting the constitutional dialogue as a "key element of the President's role as constitutional deliberator and interpreter outside the judiciary." 32 As the US Supreme Court recalled in the Immigration and Naturalization Service v. Chadha case:

"the President's participation in the legislative process was to protect the Executive Branch from Congress and to protect the whole people

\footnotetext{
27 Comprehensive Proposal for Kosovo Status Settlement, UN Doc S/2007/168/Add.1.

${ }^{28}$ Gary Gregg, The Presidential Republic: Executive Representation and Deliberative Democracy (Lanham, Rowman \& Littlefield Publishers, 1997) 70.

${ }^{29}$ R Broughton, "Rethinking the Presidential Veto" (2005) 42 Harvard Journal on Legislation 91.

${ }^{30}$ Broughton (n 29) 91.

31 On the role of the President as a guardian of the constitution see Carl Schmitt, Der Hüter der Verfassung, (Duncker \& Humblot; 1996).

32 Broughton (n 29) 91.
} 
from improvident laws. The division of the Congress into two distinctive bodies assures that the legislative power would be exercised only after opportunity for full study and debate in separate settings." 33

A textual reading of the Kosovo Constitution provides three constitutional avenues from which the President can depart in the course of the review of legislation prior to its promulgation. The first constitutional option would be if the President decides to sign a law within eight (8) days from the date of its reception at the Office of the President. This was and still is the typical approach of the presidential leadership in Kosovo. The President can simply wait and do nothing within the eight days period, and the law does enter into force ex officio without the President's promulgating act. ${ }^{34}$ The third option happens to be if the President would choose to return a law by stating written objections to the Assembly. The exercise of the President's power to return a law for reconsideration is subject to the following constitutional requirements which I will briefly analyse below.

\section{The presentment clause}

The requirement of the Kosovo Constitution that all adopted laws be presented to the President for promulgation is constitutionally unambiguous. Presentment of the approved law to the President for promulgation is clearly provided by the Constitution: "Laws adopted by the Assembly are signed by the President of the Assembly of Kosovo and promulgated by the President of the Republic of Kosovo upon her/his signature within eight (8) days from receipt." 35

According to the Rules of Procedure of the Assembly of Kosovo the laws adopted by the Assembly are initially signed by the Chairman of the Assembly within 10 working days from the day of its adoption, following which are forwarded to the President of the Republic for promulgation. ${ }^{36}$ However, there is one exception to this general rule and that is when a law, after being returned by the President based on the grounds specified by the Constitution, is approved by the Assembly. Such circumstances of course render it unnecessary for the Chairman of the Assembly to present the approved law to the President for promulgation since the approved law is considered automatically promulgated once voted by the Assembly.

\footnotetext{
33 INS v Chadha (1983) 462 US 919.

${ }^{34}$ Constitution (n 1 ) art 80 para 5.

${ }^{35}$ Constitution (n 1 ) art 80 para 2.

${ }^{36}$ Rules of Procedure (n 15) art 61.
} 


\section{THE LEGISLATIVE VETO FROM THE PERSPECTIVE OF THE KOSOVO CONSTITUTION}

\section{The exercise of the right of referral only once.}

Another limitation of the President's vetoing powers is encountered in Article 84 para. 6 of the Constitution, which defines in clear terms that the President's right for the referral of a law back to Assembly may be exercised only once. The one-time presidential veto is typical for power-sharing democracies to ensure that parliaments would not be prevented from discharging their legislative powers. It is obvious that the President's veto power is not only to rubberstamp parliamentary legislative enactments. The one-time exercise of the veto right is a sufficient mechanism to prevent navigation of improper legislation. The qualified veto power enables the President to state objections to the law by fostering debate and further discussion on the contested points of a law. The Presidential intervention in the legislative process is basically to enable the President to protect his constitutional powers in the constitutional democracy and as Hamilton has commented to "counter the passage of bad laws, through haste, inadvertence, or design." ${ }^{37}$ What Hamilton meant by "bad laws" is not sufficiently clear but as Professor Broughton argued "his meaning of a bad law is not entirely clear on its face [...] but it can be deduced that Hamilton meant to refer to something other than a law that aggrandises congressional power at the expense of the Executive." ${ }^{38}$ Although it may be considered that the use of the presidential veto only once constitutes a weak and an ineffective tool in the hands of the President to oppose the legislative attempts of the government, such an instrument is certainly an effective way to prevent the legislature from passing laws that may endanger the legitimate interests of Kosovo. Clearly in multi-party systems that are characterised with politically-fragmented parliaments, attaining the absolute parliamentary majority to overturn a decision of the President is often a difficult undertaking. But, even if it does, the President can still temporarily block the government's legislative attempt in the Assembly by contesting the enacted law before the Constitutional Court for the lack of compatibility with the Constitution.

\section{The timeframe for the review of a law.}

The deadline for the review and signing of the laws after their enactment by the Assembly is another constitutional constraint in the exercise of the Presidential legislative veto. According to Article 84 para 6 of the Constitution, the President has 8 (eight) days at its disposal to sign the law enacted by the Assembly from the date of its receipt. There is no question that

\footnotetext{
${ }^{37}$ Alexander Hamilton “The Federalist no. 73” in the R Broughton, "Rethinking the Presidential Veto” (2005) 42 Harv. J. on Legis. 105.

38 Ibid.
} 
the Constitution has followed the patterns of some regional constitutions, which have introduced similar timeframes to prevent unreasonable delays on part of the President when reviewing legislation prior to its promulgation. The question is, however, whether the eight (8) day period is sufficient to conduct a thorough legislative review. Let us first see how the timeframe of the legislative review has been addressed in some constitutions. For example, according to the Czech Constitution, "the President of the Republic has the right to return an adopted law, except a constitutional law, giving reasons, within fifteen days of the day of its transmission to the Presidency." 39 The Greek Constitution has given the President one month to review and promulgate the law voted by the Parliament, which is a period significantly lengthier than that compared to the Kosovo Constitution. ${ }^{40}$ These examples demonstrate that the assigned timeframe for the review of laws after their enactment by the Assembly is significantly longer than that provided by the Kosovo Constitution. In Kosovo, however, although it may seem that the timeframe for a review of laws prior to their promulgation is reasonable, the actual workload at the President's Legal Office shows that the eight (8) day period may not be sufficient to allow a detailed scrutiny of the enacted legislation. ${ }^{41}$ It is useful to recall that certain laws, due to their size and complexity, may require extra time and human efforts to be properly scrutinized prior to their promulgation by the President. Another difficulty is that the President's Office is sometimes confronted with a dynamic legislative activity of the Assembly, which is obvious for the country's efforts to join the European Union. In such circumstances, the timeframe for review of legislation could not be sufficient to enable the legal team to conduct a vigilant and structural review of the laws enacted by the Assembly. Therefore, as the President is not entitled to extend the timeframe set by the Constitution for the review of laws enacted by the Assembly, it may be assumed that the only possible way to ensure a longer legislative review timespan is by way of constitutional amendments. And, speaking about constitutional amendments, it should be noted that the 2008 Kosovo Constitution will most likely undergo some major changes in a near future since certain constitutional norms have resulted to be too ambiguous to enable proper functioning of constitutional bodies (such is the case with article 95 regarding the process of nominating

\footnotetext{
39 Constitution of Czech Republic, art 50. For an overview of the constitutional practices of the referral of a law back to parliament by the head of states see the Venice Commission Report on the referral of a law back to parliament by the head of state adopted by the Venice Commission at its 29th session (15-16 November 1996).

${ }^{40}$ Constitution of Greece, art 42.

${ }^{41}$ Interview with the Head of the Legal Department of the Office of the President and Lecturer of Law at the University of Prishtina (Faculty of Law) Xhafer Tahiri.
} 


\section{THE LEGISLATIVE VETO FROM THE PERSPECTIVE OF THE KOSOVO CONSTITUTION}

the candidate for Prime Minister and article 67 regarding the election of the Chairman of the Assembly).

\section{The President is not entitled to propose amendments.}

A recent judgment of the Kosovo Constitutional Court has firmly established that the President is not entitled to come up with his own amendments in the course of the review of the legislation adopted by the Assembly. ${ }^{42}$ A few words about the judgment are important here. On 15 March 2012, the Assembly adopted the Law No. 04L-084 on Pension of the members of Kosovo Security Forces [hereinafter as "Law on Pensions of KSF members"] and sent it to the President for promulgation as provided by the Constitution. On 3 April 2012 the President refused to sign the Law and decided to send it back to the Assembly for reconsideration. In its legislative return statement the President proposed insertion of a new article in the Law in order to ensure compliance with International Monetary Fund obligations and enable Kosovo to receive financial support in a form of soft loans or technical assistance. ${ }^{43}$ On its session held on 3 May 2012, the Assembly refused to incorporate the President's proposal, and the Law on Pensions of KSF members was declared as promulgated. The President contested the constitutionality of the voting of the Law on Pensions of KSF members after its return to the Assembly for reconsideration and claimed that Presidential competencies to return legislation for reconsideration were violated. ${ }^{44}$ The Constitutional Court initially assessed whether the President of the Republic, when returning the law for parliamentary reconsideration has the right to propose amendment to returned law "without challenging the adopted law or

\footnotetext{
${ }^{42}$ President Jahjaga $v$ Assembly of Kosovo [2012] KO 57/12 1 (CC). For more on the operation and jurisprudence of the Kosovo Constitutional Court see Enver Hasani/P Paczolay/M Riegner, Constitutional Justice in South East Europe. Constitutional Courts in Kosovo, Serbia, Albania and Hungary between Ordinary Judiciaries and the European Court of Human Rights (Nomos/GIZ, 2012); Visar Morina, “The Newly Established Constitutional Court in Post-Status Kosovo: Selected Institutional and Procedural Concerns” [2010] 35 Review of Central and East European Law 129; Fisnik Korenica, Dren Doli, “Kosovar Constitutional Court's Jurisdiction: Searching for Strengths and Weaknesses” [2010] 11 German Law Journal 803. Steve Hill, Paul Linden-Retek, "Supervised Independence and Post-Conflict Sovereignty: The Dynamics of Hybridity in Kosovo's New Constitutional Court” [2011] 36 Yale Journal of International Law Online 26.

${ }^{43}$ The President of the Republic proposed to the Assembly an additional paragraph to Article 27 of the Law on Pension of KSF members, as follows: "In case of lack of public funds, the Government may downsize the benefits from the law, in order it does not endanger financial security of Kosovo."

${ }^{44}$ President Jahjaga $v$ Assembly of Kosovo [2012] KO 57/12 1 (CC) para 10.
} 
any of its specific provisions.” 45 The Court ruled that it cannot. According to the Constitutional Court nowhere does the Constitution provide that the President is entitled to propose concrete amendments in the law pending promulgation. ${ }^{46}$ The Constitutional Court went on saying that the President is entitled to propose legislation based on Article 79 of the Constitution and Articles 53 para. 1 and 54 of the Rules of the Assembly. ${ }^{47}$ Because the President did not exercise that authority, but instead used the competence under Article 84 para. 6 for returning the Law for reconsideration, the referral back to the Assembly was invalid, and the Assembly never had a proper return before it - concluded the Constitutional Court. ${ }^{48}$ This Constitutional Court decision has set an important standard in the constitutional relationship between the Assembly and the President in the process of a review of legislation prior to promulgation by barring the President from proposing amendments to the law that is subject of presidential review. The Constitutional Court has rightfully echoed the position that neither the Constitution nor Rules of Procedure of the Assembly have authorised the President to suggest concrete amendments in a law that is returned to the Assembly for reconsideration. If the President would have enjoyed the right to suggest concrete amendments in a law that is approved by the Assembly, it would have certainly distorted the system of constitutional balances in the context of legal drafting process in Kosovo. Therefore, in line with the reasoning of the Constitutional Court decision, it appears to be sufficient for the President to only veto a law and send it back to the Assembly with a letter outlining the reasons for its rejection.

\section{THE USE OF THE LEGISLATIVE VETO: CHALLENGES AND CONSTRAINTS}

The powers of the President to return a law for reconsideration are broad but not unlimited from constitutional point of view. Article 84 para. 6 of the Constitution enable the President to return adopted laws for re-consideration, "when he/she considers them to be harmful to the legitimate interests of the Republic of Kosovo or one or more Communities." ${ }^{49}$ Although the language provided in Article 84 para. 6 is broad leaving ample room for interpretation,

\footnotetext{
45 President Jahjaga v Assembly of Kosovo [2012] KO 57/12 1 (CC) para 37.

${ }^{46}$ President Jahjaga $v$ Assembly of Kosovo [2012] KO 57/12 1 (CC) para 61.

47 Article 79 of the Kosovo Constitution provides: The initiative to propose laws may be taken by the President of the Republic of Kosovo from his/her scope of authority, the Government, deputies of the Assembly or at least ten thousand citizens as provided by law.

${ }^{48}$ President Jahjaga v Assembly of Kosovo [2012] KO 57/12 1 (CC) para 61.

${ }^{49}$ Constitution (n 1) art 86.
} 


\section{THE LEGISLATIVE VETO FROM THE PERSPECTIVE OF THE KOSOVO CONSTITUTION}

the Constitution has boldly underlined two constitutional areas based on which the exercise of the President's legislative veto can be made. The President is therefore bound to reflect along the categories that are implicit in Article 84 para. 6 of the Constitution. It is worth to mention that some constitutions provide no guidance with regard the scope of the presidential review of legislation prior to its promulgation..$^{50}$ According to the French Constitution, the President of the Republic promulgates acts of parliament within a period of 15 days following their final adoption and transmission to the government. But the President "may, before the expiration of this time limit, ask parliament to reconsider the act, or some of its articles. This reconsideration may not be refused." ${ }^{51}$ Similar constitutional grounds for the return of law for parliamentary reconsideration are provided by the Basic Law of the Federal Republic of Germany according to which "laws enacted in accordance with the provisions of this Basic Law shall, after countersignature, be certified by the Federal President and promulgated in the Federal Law Gazette."52 Despite enumeration of the grounds for refusal of legislation, the Kosovo Constitution has given the President a wide magnitude of reviewing powers to assess whether the enacted legislation threatens the legitimate interests of Kosovo or of one its communities. The qualification is made by the President and no other constitutional organ can make constitutional objections to the President's decision in returning a law for reconsideration. On the other hand, it is difficult to demarcate the boundaries of the President's veto powers when returning legislation for reconsideration. The exercise of the President's legislative veto largely depends on the nature of the law, its content and the manner in which the law was adopted. It is unquestionable that the President ought to defend his/her constitutional competencies provided by the Constitution against potential parliamentary intrusions. Likewise, the President ought to temporarily block constitutionally deficient legislation, which threatens constitutional rights and freedoms or endangers constitutional principles such as the separation of powers, the rule of law or the principle of democracy. ${ }^{53}$ There are essentially two major constitutional grounds upon which the legislative veto can be exercised, which will be discussed in the following section of this article.

\footnotetext{
${ }^{50}$ Venice Commission Report (n 39).

${ }^{51}$ Constitution of France 1958 art 10.

52 Basic Law of the Federal Republic of Germany 1949 art 82.

53 Broughton (n 29) 111.
} 


\section{Procedural review}

The manner in which the Assembly adopts laws, including the required majority for their adoption is regulated by the Constitution. ${ }^{54}$ There are generally three forms for approval of laws at the Assembly of Kosovo. The first and the most dominant variant is adoption of legislation by a simple majority vote. ${ }^{55}$ Certain laws, however, due to their relevance and complexity require a qualified majority of votes, including the approval of the deputies holding seats reserved or guaranteed for the Communities. This is related to the legislation of vital interest for Kosovo, for the approval of which the majority of the Assembly deputies present and voting and the majority of the Assembly deputies' present and voting holding seats reserved or guaranteed for representatives of Communities that are not in the majority is required. ${ }^{56}$ Finally, laws may be adopted by the absolute majority (which requires the majority vote of all deputies). For instance when the President returns an enacted law to Assembly for reconsideration, such law is approved by a majority vote of all its deputies. ${ }^{57}$ Until the Constitutional Court's decision on the President's legislative veto powers was issued, there has been some constitutional ambiguity concerning the manner in which the legislative veto was overridden. In a few instances legislation returned by the President was adopted based on a simple majority vote, which is in open contradiction with the Constitution. In some other cases, the Functional Committee proposal, but not the returned law as a whole, was put for voting at the plenary session, which is not what the Constitution dictates. ${ }^{58}$ This constitutional ambiguity has also been generated by the Rules of Procedure, which have not followed the language of the Constitution regarding the approval of the returned legislation by the President. Article 61 of the Rules of Procedure provides:

\footnotetext{
${ }^{54}$ Constitution (n 1) art 80.

${ }^{55}$ Article 80 para 1 of the Kosovo Constitution provides that "laws, decisions and other acts are adopted by the Assembly by a majority vote of deputies present and voting, except when otherwise provided by the Constitution."

${ }^{56}$ Constitution (n 2) art 82. The laws that require double majority voting include the laws changing municipal boundaries, establishing or abolishing municipalities, defining the scope of powers of municipalities and their participation in inter municipal and cross-border relations; Laws implementing the rights of Communities and their members, Laws on the use of language; Laws on local elections; Laws on protection of cultural heritage; Laws on religious freedom or on agreements with religious communities; Laws on education; Laws on the use of symbols, including Community symbols and on public holidays.

${ }^{57}$ Constitution (n 1 ) art 80 para 4.

${ }^{58}$ Minutes of the plenary session of the Assembly of Kosovo, P- 123 dated 27 July 2010.
} 
"If the President of the Republic returns the law for its review in the Assembly, the Presidency of the Assembly shall refer it immediately to the functional - lead committee for its review. Functional committee shall only review the issues contained in President's decision. The Committee shall, within two working weeks from the day of receipt, present to the Assembly a report with recommendations. The Assembly shall with majority of votes of all members of the Assembly decide on approval of recommendations addressing the President's remarks presented by the committee, which, together with the approved amendments, shall be considered as promulgated."

However, the Constitution suggests for a different constitutional arrangement than that provided by the Rules of Procedure on the manner in which the returned law is approved. The Constitution provides that on occasion of a return of a law by the President for reconsideration, the returned law must be approved by the majority of all the deputies of the Assembly. Article 61 of the Rules of Procedure is clearly in stark contradiction with Article 80 para. 4 of the Constitution. The following example illustrates the procedural errors that have come up in the process of dealing with the President's legislative veto. On 20 April 2012, the Assembly adopted the Criminal Code of Kosovo (hereinafter "the Code"). Media and civil society representatives were concerned with the content of Articles 37, 38 and 39 of the Code that regulated criminal liability for criminal offences committed through media, and requested from the President to veto the Law, which the President did on 4 May 2012. ${ }^{59}$ The President refused to sign the Law on the grounds that the contested articles of the Code contradicted article 40 (freedom of expression) and article 42 (freedom of media) of the Constitution. In addition, the President also invoked articles of the European Convention for the Protection of Human Rights and Fundamental Freedoms and its Protocols, which by virtue of Article 22 of the Constitution is directly applicable. ${ }^{60}$ The President's concerns were legitimate but unanticipated parliamentary developments prevented the Assembly from accommodating the Presidential constitutional objections in the Law. At its session of June 22, 2012 the Assembly debated regarding the concerns raised in the decision of the President for removal of contested articles of the Code but failed to secure an absolute majority of 61 votes to accommodate the constitutional concerns raised by the President. It is important to note that the Assembly has not put

\footnotetext{
${ }^{59}$ The contested articles of the Criminal Code of Kosovo dealt with the criminal liability of chief editors, publishers, printers or manufacturers, protecting sources of information and application of general provisions on criminal liability.

${ }^{60}$ Presidential Decree (2012) 561/1.
} 
for voting the entire law as required by the Constitution but only the recommendation of the Functional Committee requesting removal of the article 37, 38 and 39 of the Criminal Code. ${ }^{61}$ The contested provisions of the Code were removed only after the Assembly adopted the Law on Amendments to the Criminal Code on 19 October 2012. In addressing the majority voting requirement required for overriding the Presidential legislative veto, the Constitutional Court recalled the constitutional requirement for the absolute majority as laid down by Article 84 para. 4 of the Constitution. The Constitutional Court noted that "provided that the President of the Republic exercised the veto power ... in order to overturn that Presidential veto, it would be necessary that at least 61 deputies vote in favour of the adopted law that was returned by the President of the Republic." 62 This was not the case in the course of the parliamentary voting of the returned Criminal Code. Hence, it becomes clear that the President enjoys the constitutional power to ensure that the procedural requirements for the law adoption [as laid down by the Constitution and the Rules of Procedure of the Assembly] are duly observed. If the President finds out that the Assembly has failed to adhere to the procedural requirements for adopting the law, it is the constitutional duty of the President not to sign a law and to return the law to the Assembly and have the law enactment procedures repeated.

\section{Substantive review}

In the following part of this article we address the substantive grounds for review of laws before their promulgation by the President, including the parameters of this review. As noted earlier, the scope of the President's power to determine constitutionally objectionable laws is broad. This is a result of the far-reaching wording that has been employed at the Constitution, which gives the President abundant authority to negate enacted-legislation. In broad outline, the Constitution provides for two avenues for a review of legislation prior to its promulgation. The first avenue is to assess whether the enactedlaw constitutes a threat for the legitimate interests of the state. It is of course obvious that what constitutes a threat for the state interest is difficult to quantify. It all depends on the nature and the level of such threat, and whether the use of the legislative veto is prudent and proportional to achieving its goal i.e. preventing the parliamentary majority from passing constitutionally objectionable legislation. The second avenue of Presidential legislative review powers is verifying whether the enacted law adversely affects any of the vital interests of the communities as provided by the Constitution. In this regard

61 KDI, 'Minutes of the Assembly Session' (www.votaime.org 2012) <http://www.votaime.org/transkriptet/Qershor/22062012.pdf> accessed 25 July 2014.

62 President Jahjaga v Assembly of Kosovo [2012] KO 57/12 1 (CC) Para 76. 


\section{THE LEGISLATIVE VETO FROM THE PERSPECTIVE OF THE KOSOVO CONSTITUTION}

one should recall that the Constitution has devoted an entire chapter for the protection of the rights and interest of the Communities. Members of the communities have been given extra-constitutional rights in addition to those contemplated by Chapter 2 of the Constitution. ${ }^{63}$ Moreover, the Constitution provides that state authorities are obliged to respect the standards provided in the Council of Europe Framework Convention for the Protection of National Minorities and the European Charter for Regional or Minority Languages, and it establishes the Consultative Council for Communities, which acts under the authority of the President of the Republic of Kosovo in which all Communities are represented. ${ }^{64}$ The President therefore enjoys broad legislative review powers when receiving legislation for promulgation. However, a critical reading of the Constitution seem to suggest that the President should demonstrate reasonable care in preserving the integrity of the legislative process when reviewing laws passed by the Assembly as noted at the Constitutional Court's decision. In this sense as long as legislative veto is exercised within the contemplated constitutional framework i.e. when there is a substantial violation of state interests or the separation of powers to the detriment of any of the branches of the government, the use of the legislative veto is constitutionally justifiable. The uncertainty may only arise when the President acts beyond the contemplated constitutional boundaries where the legislative veto is used as Professor Broughton calls it a "policy-making device for dictating the content of national legislation." 65 And, while demarcation of the scope of the Presidential review powers implicit in article 84 para. 6 of the Constitution is difficult, there seem to be some orientating benchmarks, which could serve as a useful guide for determining whether the enacted legislation is consistent with constitutional requirements, which we will be briefly elaborate in the following section of this article.

\section{The Supremacy Clause}

It should be noted that the power of the President to defend the Constitution and to reject promulgation of constitutionally objectionable laws is unquestionable. As Professor Johnsen has written, the President can bring "a valuable perspective to the debate over the Constitution's meaning." 66 According to the constitutional supremacy clause it is the duty of the President to refuse to sign any statute with constitutional defects and to notify

63 Constitution (n 1) art 57 para 1.

${ }^{64}$ Constitution (n 1) art 60.

65 Broughton (n 29) 133.

${ }^{66}$ Dawn Johnsen, "The Constitution under Clinton: A critical assessment: Presidential Non-Enforcement of Constitutionally Objectionable Statutes” [2000] 63 Law \& Contemp. Prob. 7, 36. 
the Assembly of his constitutional objections. In Kosovo the Constitution enjoys the status of the highest legal act whereby every law and other legal acts must be in compliance with it. ${ }^{67}$ Therefore, it is the duty of the President to deter any legislation which in his view is unconstitutional. Judge Frank Easterbrook rightfully argues the power to safeguard the constitution is the duty of every branch power. According to Easterbrook "no law may go into force unless all three branches agree that it is constitutional. Each, acting within its sphere, has the power to say no: Congress not to enact, the President not to approve in his legislative role or enforce in his executive role, and the Court to set aside." ${ }^{68}$ Such prerogative according to Madison enables the President to "restrain the Legislature from encroaching on the other coordinate Departments, or on the rights of the people at large; or from passing laws unwise in their principle, or incorrect in their form." 69 The duty to protect the constitutional order is implicit in the oath text provided by the Law on the President which states

"I swear to commit all my powers to the preservation of independence, sovereignty and territorial integrity of Republic of Kosovo, to ensure human and citizen rights and freedoms, to respect and protect the Constitution and the laws, to maintain peace and welfare of all citizens of Republic of Kosovo and to conduct all my duties with consciousness and responsibility."70

Invoking the constitutional supremacy clause has been the general practice in the exercise of the legislative veto in Kosovo. For example, when the current President of Kosovo returned the Criminal Code of Kosovo (adopted on 20 April 2012) for parliamentary reconsideration on the grounds that it contained articles that curtailed down freedom of media standards, it stated incompliance provisions of the Constitution. ${ }^{71}$ Recalling the supremacy of the Constitution the President stated that adoption of the Criminal Code would create such constitutional disturbances that would adversely impact the constitutional right on freedom of expression and media, including the European Convention for the Protection of Human Rights and Fundamental

\footnotetext{
${ }^{67}$ Constitution (n 1) art 16.

68 Michael Crabb, "The Executive Branch Shall Construe": The Canon of Constitutional Avoidance and the Presidential Signing Statement” [2008] 56 Kan. L. Rev. 711, 725.

${ }^{69}$ Harold Krent, Presidential Powers (1st, New York University Press, 2005) 17.

${ }^{70}$ Law on the President 03/L-094 (2009).

${ }^{71}$ Constitution (n 1 ) art 40.
} 


\section{THE LEGISLATIVE VETO FROM THE PERSPECTIVE OF THE KOSOVO CONSTITUTION}

Freedoms and its Protocols, which by virtue of article 22 of the Constitution is directly applicable and has superiority over the laws of Kosovo. ${ }^{72}$

\section{The Separation of powers}

In one of the presidential objections the President underlined the importance of protection the separation of powers and the concept of constitutionally implied powers. This actually was one of the rarest cases when the President used the legislative return powers to protect the independent presidential constitutional powers against in what the President portrayed as the tendency of the Assembly to amputate presidential competencies contemplated by the Constitution and allocate them unconstitutionally within the Assembly portfolio. Here are the facts of the case. On 12 July 2010, the Assembly adopted the Law no. 03/L-209 on Central Bank Authority ("Law on CBA"). Following its enactment, the Law on CBA was sent to the President for promulgation. The President refused to sign the Law on the grounds that it contained provisions related to the appointment and removal of a Governor or any non-executive member of the Central Bank Board (CBB) that were contrary to the Constitution. The Constitution unequivocally provides that the President "appoints the Governor of the Central Bank of the Republic of Kosovo who will also act as its Managing Director, and appoints the other members of the Bank's Board."73 This competency falls under the independent constitutional competencies of the President whose exercise is not dependent on authority of the other constitutional organ based on the principle of checks and balances.

However, the Law on CBA provided a system for the appointment and removal of the Central Bank Board different from that of the Constitution. The Law on CBA authorized the Assembly to conduct the initial selection of the candidates for the Central Bank Board, and forward the proposed candidates to the President for endorsement. With regard to dismissal, the Law gave the Assembly the authority to initially decide for dismissal of a Governor or non-executive members of the Central Bank Board, a decision which would then be sent to the President for approval. ${ }^{74}$ However, art. 41 para 3 of the vetoed Law provided that if the President does not act on the Assembly proposed measure of dismissal within 15 days, the decision of the Assembly will enter into force. It should be recalled that competencies of the

\footnotetext{
72 President's Decree 556/01 2012

${ }^{73}$ Constitution (n 1) art 84 para 27.

74 Law No.03/L -209 on Central Bank of the Republic of Kosovo. Article 41 regulated the disqualification and removal from the Central Bank Board. Law entered into force after having been returned for parliamentary reconsideration and voted by the AoK on 27 July 2010.
} 
Assembly are contemplated in Article 65 of the Constitution, and nowhere does the Constitution vests the Assembly with authority to propose to the President candidates for appointment at the CBB. Departing from this constitutional ground, the President refused to sign the Law on CBA arguing that the Law violated the apportionment of constitutional competencies provided by the Constitution and violated the principle of the separation of powers that is inherent in the Constitution. In President's understanding, enactment of the Law on CBA was a blatant invasion by the Assembly of the constitutionally-independent prerogatives of the President on the appointment of a Governor another members of the CBB. The President argued that promulgation of the Law would seriously jeopardise the legitimate interests of Kosovo and would prevent the President from fulfilling his constitutional duty as a guarantor of the constitutional functioning of state institutions. On 27 July 2010, the Assembly decided with absolute majority to accept the President's proposal and modify article 43 para 1 . of the Law that provided for the entry into force of the Assembly decision on dismissal in case the President fails to endorse the proposal within 15 days. ${ }^{75}$ Surprisingly, the Assembly voted only the President's concrete recommendation stated at the Decree but not the returned Law on CBA as required by the Constitution. In an attempt to accommodate the President's constitutional objections, the Assembly only inserted a paragraph providing that "the President can approve or not approve the Assembly proposal for dismissal of the Governor or any member of the Central Bank Board of Kosovo." However, despite the approval of the Presidential return statement, the assumed responsibilities of the Assembly on appointments or dismissals at the Central Bank Authority could not be fully justified on constitutional grounds.

\section{International Law}

The Constitution of Kosovo offers another avenue of the Presidential review of laws adopted by the Assembly: compliance with international law. Therefore a few words about the status of the international law in the Kosovo Constitution are important to be mentioned here. The Constitution pursues a friendly approach towards international law. The Constitution not only contemplates the primacy of the international law versus ordinary legislation but it also gives direct effect in terms of application to some of the most important international human rights instruments enumerated in Article 22 of the Constitution. Hence, the Constitution's approach in Kosovo seems to correspond to the doctrine of monism whereby norms of international law are considered an integral part of the national legal system. This is clearly

\footnotetext{
75 The official transcript on the Plenary Session of the Assembly of Kosovo, dated 27 July 2010, is available at the official site of the Assembly of Kosovo.
} 


\section{THE LEGISLATIVE VETO FROM THE PERSPECTIVE OF THE KOSOVO CONSTITUTION}

provided in Article 19 of the Constitution which states that "ratified international agreements become part of the internal legal system after their publication in the Official Gazette in Kosovo" and become directly applicable "except for cases when they are not self-applicable and the application requires the promulgation of a law."76 This primacy and direct applicability of international law in the Kosovo legal system is considered by some international law scholars as a "highly progressive approach to international law."77

The Constitution further provides that main international human rights instruments, including the European Convention for the Protection of Human Rights and Fundamental Freedoms (ECHR) and its Protocols, are directly applicable "and, in the case of conflict, have priority over provisions of laws and other acts of public institutions." 78 That said, it is perfectly adequate for the President to extend the scope of presidential review by taking into account the requirements of the applicable international law with the enacted legislation. For this purpose the President has recently shown special consideration towards reliance on international law in legislative veto practices. One recent example is the decision to return the Criminal Code for reconsideration where the President has invoked provisions of the ECHR in

${ }^{76}$ Constitution (n 1 ) art 19 para 1. See Williman Slomanson, Fundamental perspectives on international law (Cengage Learning, 2010) 17.

77 See Gideon Boas, Public international law: contemporary principles and perspectives (Edward Elgar Publishing, 2012) p 153. See also Visar Morina, Fisnik Korenica, and Dren Doli. "The relationship between international law and national law in the case of Kosovo: A constitutional perspective.” [2011] International journal of constitutional law 274. See also Armin Von Bogdandy "Pluralism, direct effect, and the ultimate say: On the relationship between international and domestic constitutional law.” [2008] International Journal of Constitutional Law (2008) 397.

${ }^{78}$ Constitution (n 1) art 22. Providing for the direct applicability of international agreements and instruments the Constitution in its Article 22 provides that 'Human rights and fundamental freedoms guaranteed by the following international agreements and instruments are guaranteed by this Constitution, are directly applicable in the Republic of Kosovo and, in the case of conflict, have priority over provisions of laws and other acts of public institutions: (1) Universal Declaration of Human Rights; (2) European Convention for the Protection of Human Rights and Fundamental Freedoms and its Protocols; (3) International Covenant on Civil and Political Rights and its Protocols; (4) Council of Europe Framework Convention for the Protection of National Minorities; (5) Convention on the Elimination of All Forms of Racial Discrimination; (6) Convention on the Elimination of All Forms of Discrimination Against Women; (7) Convention on the Rights of the Child; (8) Convention against Torture and Other Cruel, Inhumane or Degrading Treatment or Punishment. 
the same degree with provisions of the Constitution. ${ }^{79}$ Not only that it is convenient for the President to check the enacted legislation based on the international law, but according to Article 53 of the Constitution any interpretation of the human rights and fundamental freedoms that are guaranteed by the Constitution must be done in the manner that is "consistent with the court decisions of the European Court of Human Rights.” The President is therefore obligated that in the course of reviewing legislation enacted by the Assembly to ensure that the norms of ratified international agreements or of those international human rights instruments that are directly applicable are not violated. It is for this reason that the tendency to uphold international law in reviewing legislation prior to its promulgation in Kosovo is increasing. Reliance on international law and particularly on the ECHR is evident for the legislation affecting human rights and fundamental freedoms. As noted earlier the ECHR enjoys a legal status that is higher than the ordinary legislation, and the Constitutional Court of Kosovo has repeatedly reminded state institutions that observance of the ECHR and its jurisprudence on matters involving human rights interpretations is of an immense importance. $^{80}$

\section{Decisions of the Constitutional Court}

The interesting aspect concerning the use of the Presidential powers in the area of law review is not whether the President has the power to interpret the enacted law for compatibility with the Constitution but whether the President can veto legislation based on constitutional understandings that contradict understandings implicit in prior Constitutional Court judgments? In other words the question is whether the President is obliged to follow constitutionally conforming interpretations made by the Kosovo Constitutional Court in the course of the review of laws enacted by the Assembly? In light of these questions it is worth noting that Kosovo has opted for a centralized version of constitutional review where the authority to resolve a constitutional controversy is vested with the Constitutional Court whose judgments are obligatory to all and have the force of law. Article 116 para. 1 of the Constitution provides that "decisions of the Constitutional Court are binding on the judiciary and all persons and institutions of the Republic of

\footnotetext{
${ }^{79}$ President's Decree 556/01 2012.

${ }^{80}$ See for example Gëzim and Makfire Kastrati against Municipal Court in Prishtina and Kosovo Judicial Council [2012] KI 41/12 (CC); Valon Bislimi v Ministry of Internal Affairs, Kosovo Judicial Council and Ministry of Justice [2010] KI 06/10 (CC); Imer Ibrahimi and 48 Other Former Employees of the Kosovo Energy Corporation $v 49$ Individual Judgments of the Supreme Court of the Republic of Kosovo [2010] KI 40/09 (CC).
} 


\section{THE LEGISLATIVE VETO FROM THE PERSPECTIVE OF THE KOSOVO CONSTITUTION}

Kosovo." This means that respect and adherence to the decisions of the Constitutional Court is constitutionally imperative for every public institution including the President when acting as a law promulgator. Moreover, the legislation in Kosovo has introduced some further limitations to the President when an adopted law gets challenged for its constitutionality prior to its promulgation. According to the Kosovo Constitution "ten (10) or more deputies of the Assembly of Kosovo, within eight (8) days from the date of adoption, have the right to contest the constitutionality of any law or decision adopted by the Assembly as regards its substance and the procedure followed." 81 The Law on the Constitutional Court provides that the law adopted by the Assembly can be sent to the President for promulgation after the expiry of the deadline provided in Article 113 para. 5 of the Constitution. But in the event that a law adopted by the Assembly is contested on the grounds of constitutionality, the law is sent to the President of the Republic of Kosovo for promulgation "in accordance with modalities determined in the final decision of the Constitutional Court." 82 The Constitutional Court recently warned the President not to promulgate the Law on Amnesty, which was contested on the grounds of constitutionality within 8 days since its enactment. ${ }^{83}$ In its press release the Constitutional Court has reminded the constitutional organs that "any attempt to publish the Law or to apply it is unconstitutional and such an act is null and void." ${ }^{44}$ Until the time of writing, the Constitutional Court has not yet ruled on the constitutionality of the Amnesty Law.

\section{CONCLUSION}

This article has sought to define the way in which the presidential legislative veto is exercised in Kosovo by taking into account the procedural and substantive factors that are inherent in the course of the legislative review process. By focusing on the Kosovan sources of constitutional law, including its national constitutional jurisprudence, the article has attempted to deconstruct the meaning and parameters of the President's legislative veto powers in a parliamentary-type government. Six years after the adoption of

\footnotetext{
${ }^{81}$ Constitution (n 1 ) art 113 para 5.

${ }^{82}$ Law on the Constitutional Court 2008 art 43.

83 The Law on Amnesty was contested by the Assembly members from the political movement "Vetvendosja" claiming that the Law infringed human rights and fundamental freedoms guaranteed by the Constitution, including the International Covenant for the Civil and Political Rights that is directly applicable in Kosovo under Article 22 of the Constitution.

${ }^{84}$ Constitutional Court Press Release, dated 25 July 2013 accessible at http://gjkks.org/?cid=2,28,344.
} 
the Kosovo Constitution, the application of the Presidential legislative veto to refrain the Assembly from passing constitutionally deficient legislation has encountered many challenges. In some cases, this was a result of the constitutionally ambiguous norms while in other cases this may be related to the lack of understanding of the current legislative complexities. As the above mentioned developments in post-status Kosovo have unfolded, establishment of a well-structured constitutional dialogue in dealing with Presidential return statements both at procedural or substantive grounds has proven to be a difficult undertaking. The lack of a constitutionally-consistent approach for overturning the Presidential legislative veto is one the clear examples of the challenges that have confronted the application of the legislative veto in Kosovo. Such situation rendered the involvement of the Constitutional Court necessary, which in its 2012 interpretative decision tended to define the procedural dimension of the legislative veto. There is no doubt that constructive improvement of the legislative products is an essential requirement for a rule of law what makes the presidential legislative veto highly important. However, as Professor Spitzer has emphasised commenting the strategic use of the presidential veto in the United States of America even the veto threat often accomplishes "the purpose of an actual veto". ${ }^{85}$ In the case it does not, its use to appeal to the public could also be an effective instrument to refrain the legislators from passing unconstitutional legislation. This is a valid point that deserves consideration in the constitutional landscape of Kosovo for as long as the legislative veto is exercised with prudence and pragmatism in order to safeguard the separation of powers being firmly embedded in our Constitution.

85 Robert Spitzer, "Why Obama Must Embrace the Veto Strategy" (http://www.huffingtonpost.com 2011) <http://www.huffingtonpost.com/robert-jspitzer/time-for-an-obama-veto-st_b_803359.html> accessed 25 July 2014. 